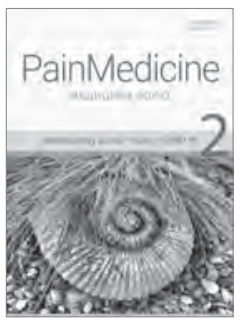

DOI: 10.31636/pmjua.t1.27197

\title{
Реабілітаційне обстеження жінок з лімфостазом
}

\author{
Бас О. А., Гречин В. М. \\ Львівський державний університет фізіичної культури, м. Львів, Україна
}

Актуальність. Лімфостаз - гостре порушення лімфатичного відтоку, що супроводжується стійким набряком і збільшенням кінцівки в розмірі з подальшим фіброзом шкіри та підшкірної клітковини, утворенням виразок і розвитком слоновості. Набряк, який не лікується, може перейти в хронічну стадію і викликати обмеження рухливості, у важких випадках - злоякісні пухлини в ушкодженій ділянці (лімфангіосаркома). Якісне реабілітаційне обстеження дозволить розробити програму фізичної терапії для тривалого терапевтичного ефекту.

Мета дослідження: розробити базове реабілітаційне обстеження жінок 3 лімфостазом.

Матеріали та методи. Аналіз літературних джерел за темою дослідження.

Результати дослідження та їх обговорення. Анкетування та збір анамнезу проводиться для визначення обізнаності пацієнток про захворювання, рівень рухової активності та функціональних порушень.

Для визначення рівня якості життя рекомендовано опитувальник функціонального оцінювання FACT-B+4 (Functional Assessment of Cancer Therapy) та Lymphoedema Quality of Life ARM.

Для виявлення психоемоційного стану рекомендовано «Шпитальну шкалу депресії та тривоги» (HADS).

Діагностика болю включає локалізацію, інтенсивність, характер та механізм ви- никнення, рекомендовано використовувати шкалу болю ВАШ та опитувальник МакГілла.

Складовими фізикального обстеження є огляд: виявлення порушень постави, патологічних положень кінцівок і тулуба, локалізація набряку; наявність деформацій, шкірних складок, еритеми та інших змін на шкірі.

Для визначення консистенції набряку та ознаки Стеммера проводиться пальпація.

Обстеження стану опорно-рухового апарату включає вимірювання обхватів ураженої кінцівки, гоніометрію. Для визначення функціональності кінцівки рекомендовано тест Constant Score або Simple Shoulder Test.

При зменшенні сили м'язів рекомендовано проводити кистьову динамометрію та мануальне м'язове тестування, при неврологічних порушеннях - тестування чутливості та рефлексів кінцівки.

Висновки. За результатами аналізу літературних джерел та власних досліджень підібрано ефективні методи реабілітаційного обстеження, розроблено картку реабілітаціійного обстеження жінок з лімфостазом.

Перспективи подальших досліджень: розширення кількості методів обстеження для моніторингу за станом здоров'я жінок з лімфостазом.

Ключові слова: лімфостаз, обстеження, жінка. 